Original article (Orijinal araştırma)

\title{
Determination of the host status of some plant species with four different garlic populations of Ditylenchus dipsaci (Kühn, 1857) Filipjev, 1936 (Tylenchida: Anguinidae) ${ }^{1}$
}

\author{
Bazı bitki türlerinin Ditylenchus dipsaci (Kühn, 1857) Filipjev, 1936 (Tylenchida: Anguinidae)'nin \\ dört farklı sarımsak popülasyonuna karşı konukçuluk durumlarının belirlenmesi \\ Atilla ÖCAL ${ }^{*}$ \\ Elif YAVUZASLANOĞLU 5 \\ Gülay BEŞiRLíi \\ İbrahim Halil ELEKCiOĞLU6
}

\begin{abstract}
Stem and bulb nematode, Ditylenchus dipsaci (Kühn, 1857) Filipjev, 1936 (Tylenchida: Anguinidae) is widely distributed in areas where garlic is grown commercially in Turkey. One of the suitable methods for control of $D$. dipsaci under field conditions is rotation with non-host plant species. Thus, it is necessary to determine the host status of the plant species that can be used in rotation with the garlic plant. For this purpose, the host status of eight different plant species for four $D$. dipsaci populations obtained from important garlic growing areas was investigated in 2017 and 2018. The experiments were conducted with four replicates of treatments with nematode and without nematodes in a control environment room. Each plant was inoculated with 200 nematodes of the respective population. Six weeks after inoculation, the final nematode population in the plants and reproduction factors were determined. For all nematode populations, daffodil was an excellent host with reproduction factor $\left(R_{f}\right)$ of 5.0-6.2. Onion and garlic plants were good hosts with $R_{f}$ of 3.2-3.8 and 2.1-2.5, respectively. Lucerne, chickpea, leeks, lettuce and wheat were determined to be non-host species with $R_{f}$ 0.6-0.7, 0.5-0.8, 0,0 and 0.3-0.5, respectively. It was concluded that these non-host plant species can be used as rotational crops in the garlic production areas infested with $D$. dipsaci.
\end{abstract}

Keywords: Host, plant parasitic nematode, race, rotation, stem and bulb nematode

\section{Öz}

Soğan sak nematodu, Ditylenchus dipsaci (Kühn, 1857) Filipjev, 1936 (Tylenchida: Anguinidae) Türkiye'de ekonomik olarak sarımsak yetiştiriciliği yapılan üretim alanlarında yaygın olarak bulunmaktadır. Ditylenchus dipsaci"nin tarla koşullarında mücadelesi için uygun yöntemlerden birisi de konukçu olmayan bitki türleri ile rotasyon uygulamalarıdır. Bu nedenle sarımsak bitkisi ile rotasyona girebilecek bitki türlerinin nematoda konukçuluk durumlarının belirlenmesi önem arz etmektedir. Bu amaçla çalışmada sekiz farklı bitki türünün önemli sarımsak yetiştirme alanlarından elde edilen dört farklı D. dipsaci popülasyonuna karşı konukçuluk durumları 2017-2018 yıllarında araştırımış̧ır. Denemeler iklim odası şartlarında nematodlu ve nematodsuz bitkiler için dört tekerrürlü olarak yürütülmüştür. Nematodlu bitkilere bitki başına 200 nematod inokule edilmiştir. İnokulasyondan altı hafta sonra bitkilerdeki sonuç nematod popülasyonu belirlenerek üreme faktörleri belirlenmiş̧tir. Çalışmada bütün nematod popülasyonları için, nergis bitkisi 5.0-6.2 arasında üreme faktörü $\left(\mathrm{R}_{\mathrm{f}}\right)$ ile mükemmel konukçu olarak belirlenmiştir. Soğan ve sarımsak bitkileri sırasıyla 3.2-3.8 ve 2.1-2.5 $\mathrm{R}_{\mathrm{f}}$ ile iyi konukçu olarak tespit edilmiştir. Yonca, nohut, pırasa, marul ve buğday bitki türleri sırasıyla 0.6-0.7, $0.5-0.8,0,0$ ve $0.3-0.5, R_{f}$ değerleri ile konukçu olmayan bitki türleri olarak belirlenmiştir. Gerçekleştirilen bu çalışma ile konukçu olmayan bitki türlerinin soğan sak nematodunun bulaşık olan üretim alanlarında rotasyon bitkisi olarak kullanılabileceği sonucuna varıımıştır.

Anahtar sözcükler: Bitki paraziti nematod, ırk, konukçu, münavebe, soğan-sak nematodu

1 This study was supported by the General Directorate of Agricultural Research and Policies, Turkey, Grant Project No: TAGEM/BSAD/A/18/A2/P1/380. This study was undertaken as a part of PhD Thesis in Çukurova University, Institute of Science, Department of Plant Protection, Adana, Turkey.

2 Directorate of Atatürk Horticultural Central Research Institute, Department of Plant Protection, 77100, Yalova, Turkey

${ }^{3}$ Directorate of Atatürk Horticultural Central Research Institute, Department of Vegetable Agronomy and Breeding, 77100, Yalova, Turkey

${ }^{4}$ Directorate of Plant Protection Central Research Institute, Department of Entomology, 06172, Ankara, Turkey

${ }^{5}$ Karamanoglu Mehmetbey University, Technical Sciences Vocational School, Department of Plant and Animal Production, 70100, Karaman, Turkey

${ }^{6}$ Cukurova University, Faculty of Agriculture, Department of Plant Protection, 01330, Sarıçam, Adana, Turkey

* Corresponding author (Sorumlu yazar) e-mail: atilla_ocal@hotmail.com

Received (Alınış): 20.04.2021Ａccepted (Kabul ediliş): 11.08.2021 


\section{Introduction}

Garlic is an economically important commodities in Turkey and worldwide. The main nematode constraint for garlic production is stem and bulb nematode, Ditylenchus dipsaci (Kühn, 1857) Filipjev, 1936 (Tylenchida: Anguinidae). Infected garlic plants show stunting, yellowing of leaves and shoots, deformation and abnormal cell growth in leaves and stems, lesions range from yellow to dark brown in the bulbs. The nematode reduces product quality and causes economically significant yield loses. In onion and bulbous ornamental plants, $5-100 \%$ damage can occur due to D. dipsaci (Duncan \& Moens, 2006). Ditylenchus dipsaci is widely distributed in areas with temperate climates (Abd-Elgawad \& Askary, 2015) and is reported from most of the onion and garlic production areas of Turkey (Mennan, 2001; Yavuzaslanoglu et al., 2019; Ocal, 2021).

Ditylenchus dipsaci has the greatest intraspecific difference in the host range of plant parasitic nematodes and therefore has the greatest number of synonyms with thirteen nominal species (Subbotin et al., 2005). The classification of this nematode is made at the race level according to the host status of the plants. There are more than 30 races that can multiply on economically important plant species (Sturhan \& Brzeski, 1991). Seinhorst (1957) identified 11 different races of $D$. dipsaci using nine different plant species. Accordingly, he reported that onion [Allium cepa L. (Asparagales: Amaryllidaceae)], garlic [Allium sativum L. (Asparagales: Amaryllidaceae)] and pea [Pisum sativum L. (Fabales: Fabaceae)] were among the hosts of the onion race. Thorne (1961) reported that the hosts of the onion race of $D$. dipsaci were rice [Oryza sativa L. (Poales: Poaceae)], hyacinth [Hyacinthus orientalis L. (Asparagales: Asparagaceae)], daffodil [Narcissus spp. L. (Asparagales: Amaryllidaceae)], thistle (Silybum marianum (L.) Gaertn. (Asterales: Asteraceae)] and parsley [Spinacia oleracea L. (Caryophyllales: Amaranthaceae)]. Eight races of $D$. dipsaci were defined by Janssen (1994) according to the plant from which they were obtained. The races determined by Janssen (1994) were lucerne [Medicago sativa, L. (Fabales: Fabaceae), red clover [Trifolium pratense L. (Fabales: Fabaceae)], oat [Avena sativa L. (Poales, Poaceae)], rye [Secale cereale L. (Poales, Poaceae)], sugar beet [Beta vulgaris L. (Caryophyllales: Amaranthaceae)], daffodil, tulip [Tulipa spp. L. (Liliales: Liliaceae)] and onion. Shubina (1992) reported that the onion race of $D$. dipsaci did not feed on maize [Zea mays L. (Poales: Poaceae)] but fed and reproduced on rice and pea. The host status of $D$. dipsaci obtained from onion in Amasya Suluova District in Turkey was investigated by Mennan (2001). Yavuzaslanoglu \& Aksay (2021) reported susceptibility of plant species to onion and garlic populations of $D$. dipsaci from the Central Anatolia Region in Turkey. Viglierchio (1971) reported that the host status of local populations may be different. Therefore, the hosts of nematode populations that are distributed in different locations should be determined. However, the host status of different plant species to $D$. dipsaci populations obtained from different garlic production areas where most of the garlic production is undertaken has not been investigated widely in Turkey.

Therefore, the aim of this study was to investigate the host status of eight plant species using four D. dipsaci populations from garlic grown in production areas of Turkey.

\section{Materials and Methods}

\section{Nematode populations}

Ditylenchus dipsaci populations were collected in 2017 and 2018 from Adıyaman, Gaziantep, Kahramanmaraş and Kastamonu Provinces, Turkey, in areas with intensive garlic production. Nematode populations were identified as $D$. dipsaci (Ates Sonmezoglu et al., 2020). Location information about $D$. dipsaci populations is given in Table 1. 


\section{Mass production of pure cultures of Ditylenchus dipsaci populations}

Stem and bulb nematodes obtained from the samples did not contain sufficient numbers to be used directly and were not pure populations. Therefore, pure cultures of $D$. dipsaci populations were propagated by the carrot culture method using nematodes obtained from plant samples. Sterile carrot discs were prepared in 2017-2019 in Atatürk Horticultural Central Research Institute, Yalova, Turkey (Chitambar, 2003; Kühnhold et al., 2006). Firstly, the carrots that were washed in tap water, drained and peeled then placed $97 \%$ ethanol for $10-15 \mathrm{~min}$. Then carrots were peeled again with a sterile knife, sliced into $\sim 1 \mathrm{~cm}$ thick disc and placed individually in Petri dishes. One female and one male Ditylenchus dipsaci were transferred to each sterile carrot disc. Cultures were incubated at $19-20^{\circ} \mathrm{C}$ in the dark. Discs were cut into small pieces and placed on fresh sterile carrot discs for 2-4 months to maintain the cultures for use as inoculum (after extraction) for host status determination.

Table 1. Geographic locations of Ditylenchus dipsaci populations

\begin{tabular}{|c|c|c|c|c|c|c|}
\hline Populations & Region & Province & District & Village & Latitude & Longitude \\
\hline ADY1 & South East Anatolia & Adıyaman & Tut & Yeşilyurt & $37^{\circ}-44^{\prime} 55.55^{\prime \prime} \mathrm{N}$ & $38^{\circ} 01 ' 08.55^{\prime \prime E}$ \\
\hline GAZ4 & South East Anatolia & Gaziantep & Oğuzeli & Koçaklar & $36 \div 52 ' 57.73 " \mathrm{~N}$ & 37운'57.40"E \\
\hline $\mathrm{KAH} 2$ & Mediterranean & Kahramanmaraş & Pazarcık & Narlı/Karaçay & $37^{\circ}-22^{\prime} 13.96 " \mathrm{~N}$ & $37^{\circ} 07^{\prime} 54.63^{\prime \prime E}$ \\
\hline KAS9 & Black Sea & Kastamonu & Taşköprü & Vakıfbelören & $41^{\circ} 30^{\prime} 07.37 " \mathrm{~N}$ & 34ำ15'01.19"E \\
\hline
\end{tabular}

\section{Host status experiment}

The plant species included in the experiment were wheat, lettuce, daffodil, chickpea, leek, garlic, onion and lucerne (Table 2).

Table 2. The cultivars and sources of the plant species used for host status determination

\begin{tabular}{lll}
\hline Plant species & Cultivar name & Source \\
\hline Chickpea (Cicer arietinum L.) & Azkan & Altat Agriculture, Çorum, Turkey \\
Daffodil (Narcissus tazetta L.) & Karaburun & Ege University, Department of Horticulture, İzmir, Turkey \\
Garlic (Allium sativum L.) & Taşköprü 56 & Atatürk Horticultural Central Research Institute, Yalova, Turkey \\
Leek (Allium porrum L.) & İnegöl 92 & Atatürk Horticultural Central Research Institute, Yalova, Turkey \\
Lettuce (Lactuca sativa L.) & Grise maraichere & Atatürk Horticultural Central Research Institute, Yalova, Turkey \\
Lucerne (Medicago sativa L.) & Bilensoy & Intfa Agriculture, Konya, Turkey \\
Onion (Allium cepa L.) & Kantartopu 3 & Atatürk Horticultural Central Research Institute, Yalova, Turkey \\
Wheat (Triticum aestivum L.) & Flamura 85 & Altınbaşak Seed, Edirne, Turkey \\
\hline
\end{tabular}

Experiment was conducted in a controlled environment room at the Atatürk Horticultural Central Research Institute, Yalova, Turkey in 2019. In the experiment, sand, field soil and farm manure were sterilized, mixed in a ratio of 70:29:1 and added to $12.5 \times 12.5 \times 20 \mathrm{~cm}$ pots $(2.5 \mathrm{~L})$. One seed of each plant species was planted per pot. Four weeks after planting, when the plants were at the three- to four-leaf stage, $10 \mu \mathrm{l}$ of $1 \%$ carboxymethyl cellulose solution containing 200 nematodes was dropped at the leaf base of each plant (Kühnhold et al., 2006). Non-inoculated plants of each cultivar were used as controls. The pots were arranged in a completely randomized design with four replicates and plants were grown at $20-25^{\circ} \mathrm{C}$ and $70-80 \% \mathrm{RH}$ in a 16:8 $\mathrm{h} \mathrm{L}: \mathrm{D}$ photoperiod. Six weeks after inoculation, plants were harvested and the plant growth parameters (plant height, stem diameter, number of leaves, root length, and combined shoot and root fresh weight) were measured. To extract nematodes, inoculated plants were cut into $1 \mathrm{~cm}$ pieces and placed in 15-cm Petri dishes according to a modified Baermann funnel technique for $48 \mathrm{~h}$ (Hooper et al., 2005). The extracted nematodes were counted under a stereomicroscope. The reproduction 
factor $\left(R_{\mathrm{f}}\right)$, calculated as the number of nematodes obtained per plant at harvest divided by the 200 nematodes initially inoculated to the plant, was used to determine the host status of the test plants. Plant species were categorized as non-host with $R_{f}<1$, poor host with $1 \leq R_{f}<2$, good host with $2 \leq R_{f} \leq 4$ and excellent host with $R_{f}>4$ (Hajihassani et al., 2016).

\section{Statistical analysis}

One-way analysis of variance was applied to the values of $D$. dipsaci ADY1, GAZ4, KAH2 and KAS9 populations in wheat, chickpea, daffodil, garlic, onion and lucerne. Differences between the treatments were evaluated using Tukey test at $P \leq 0.05$. Comparison biplot analysis was conducted to determine the relationship between $D$. dipsaci populations and hosts in terms of reproduction factors of nematode populations on host plants. Differences in plant parameters between nematode inoculated and uninoculated treatments for each plant species with each nematode population were compared by t-test. Statistical analyses were performed using JMP (13 ${ }^{\text {th }}$ ed.) and GenStat $\left(14^{\text {th }}\right.$ ed.) software.

\section{Results}

No nematodes were extracted from any inoculated lettuce and leek plants at harvest. However, nematodes were obtained from chickpea, daffodil, garlic, lucerne, onion and wheat plants. $R_{f}$ values of all D. dipsaci populations ranged between 0.5-0.8 with chickpea, 5.0-6.2 with daffodil, 2.1-2.5 with garlic, 0.60.7 with lucerne, 3.2-3.8 with onion and 0.3-0.5 with wheat (Table 3).

Population-host interaction was statistically significant $(F=1.9, \mathrm{sd}=7.21, \mathrm{P}<0.05)$. Daffodil plants $\left(R_{f}=5.3\right)$ were rated as excellent hosts $\left(R_{f}>4\right)$ whereas onion $\left(R_{f}=3.4\right)$ and garlic $\left(R_{f}=2.3\right)$ were rated as good hosts for all nematode populations $(2 \leq \mathrm{Rf} \leq 4)$. Chickpea, leek, lettuce, lucerne and wheat plants were non-hosts for all nematode populations $\left(R_{f}<1\right)$. The average $R_{f}$ of the populations was between 0.3 and 0.8 for chickpea, lucerne and wheat, while no nematode was extracted from lettuce and leek (Table 3 ).

Table 3. Reproduction factor for Ditylenchus dipsaci in different plant species in a pot experiment conducted in a growth room

\begin{tabular}{|c|c|c|c|c|c|c|c|c|}
\hline \multirow{2}{*}{$\begin{array}{l}\text { Ditylenchus } \\
\text { dipsaci } \\
\text { populations }\end{array}$} & \multicolumn{8}{|c|}{ Plant species } \\
\hline & Chickpea & Daffodil & Garlic & Leek & Lettuce & Lucerne & Onion & Wheat \\
\hline ADY1 & $0.7 \pm 0.1 \mathrm{Ad}^{1}$ & $5.0 \pm 0.9 \mathrm{Ba}$ & $2.2 \pm 0.3 A c$ & $0.0 \pm 0.0 \mathrm{Ad}$ & $0.0 \pm 0.0 \mathrm{Ad}$ & $0.6 \pm 0.2 \mathrm{Ad}$ & $3.3 \pm 0.3 \mathrm{Ab}$ & $0.5 \pm 0.1 \mathrm{Ad}$ \\
\hline GAZ4 & $0.5 \pm 0.2 \mathrm{Ad}$ & $5.2 \pm 0.4 \mathrm{Ba}$ & $2.3 \pm 0.7 \mathrm{Ac}$ & $0.0 \pm 0.0 \mathrm{Ad}$ & $0.0 \pm 0.0 \mathrm{Ad}$ & $0.6 \pm 0.1 \mathrm{Ad}$ & $3.2 \pm 0.4 \mathrm{Ab}$ & $0.4 \pm 0.1 \mathrm{Ad}$ \\
\hline $\mathrm{KAH} 2$ & $0.8 \pm 0.1 \mathrm{Ad}$ & $5.0 \pm 0.5 \mathrm{Ba}$ & $2.5 \pm 0.5 \mathrm{Ac}$ & $0.0 \pm 0.0 \mathrm{Ae}$ & $0.0 \pm 0.0 \mathrm{Ae}$ & $0.7 \pm 0.2 \mathrm{Ad}$ & $3.4 \pm 0.4 \mathrm{Ab}$ & $0.3 \pm 0.1$ Ade \\
\hline KAS9 & $0.6 \pm 0.2 \mathrm{Ad}$ & $6.2 \pm 0.4 \mathrm{Aa}$ & $2.1 \pm 0.9 \mathrm{Ac}$ & $0.0 \pm 0.0 \mathrm{Ad}$ & $0.0 \pm 0.0 \mathrm{Ad}$ & $0.7 \pm 0.2 \mathrm{Ad}$ & $3.8 \pm 0.5 \mathrm{Ab}$ & $0.5 \pm 0.1 \mathrm{Ad}$ \\
\hline
\end{tabular}

${ }^{1}$ Data are means of four replicates \pm standard deviation. Means followed by the same lowercase letter within rows (plant species) or the same uppercase letters within columns (nematode populations) are not significantly different $(P<0.05$, Tukey test).

No statistically significant differences between $R_{f}$ values for nematode populations were found except for daffodil. In the daffodil, $R_{f}$ of the KAS9 population was higher than other populations $(P<0.05)$.

The relationship between nematode populations and plant species was explained by comparison biplot analysis with a rate of almost $100 \%$ (Figure 1). The features close to the middle horizontal axis (PC1) were stable, while the stability of the features moving away from the axis was low. Also, the further a feature is located from the vertical axis (PC2) towards the right side (in the direction of the arrow) of the graph the stronger the relationship, and relationships are weaker towards the left side of the axis. According to the biplot, all the nematode populations examined formed a group. The stability of $R_{f}$ on plant species of the ADY1 and GAZ4 nematode populations was greater (Figure 1). The biplot analysis showed that the stability of the onion plant was higher and the stability of the daffodil and garlic plants was lower. Chickpea, lucerne and wheat, with low $\mathrm{R}_{\mathrm{f}}$, and lettuce and leek plants with no reproduction were grouped together. The stability of lucerne plant was found to be higher compared to chickpea and wheat. 
Most of the plant growth parameters for daffodil were significantly lower with inoculation compared to the controls for the different populations of $D$. dipsaci. Plant height was not adversely affected by the presence of KAH2 whereas there was significant reduction with the ADY1, GAZ4 and KAS9 populations (Table 4). Similarly, root height was significantly reduced by ADY1 and GAZ4 populations (Table 4).

Table 4. Percentage change in plant growth parameters in plant species inoculated with four Ditylenchus dipsaci populations

\begin{tabular}{|c|c|c|c|c|c|c|c|}
\hline $\begin{array}{c}\text { Plant } \\
\text { species }\end{array}$ & $\begin{array}{l}\text { Nematode } \\
\text { population }\end{array}$ & $\begin{array}{l}\text { Shoot } \\
\text { length }\end{array}$ & $\begin{array}{c}\text { Number of } \\
\text { leaves }\end{array}$ & $\begin{array}{c}\text { Shoot } \\
\text { diameter }\end{array}$ & $\begin{array}{l}\text { Plant } \\
\text { fresh }\end{array}$ & $\begin{array}{l}\text { Root } \\
\text { length }\end{array}$ & $\begin{array}{c}\text { Number of } \\
\text { roots }\end{array}$ \\
\hline \multirow{4}{*}{ Chickpea } & ADY1 & -10.0 & -13.0 & -22.2 & -37.1 & -33.9 & -25.9 \\
\hline & GAZ4 & -2.8 & 0.0 & 5.5 & -11.4 & -53.9 & -30.1 \\
\hline & $\mathrm{KAH} 2$ & -20.3 & -13.0 & $-38.8^{*}$ & -34.3 & -34.5 & -24.9 \\
\hline & KAS9 & -19.7 & $-56.5^{*}$ & -38.8 & -40.0 & -51.5 & -22.3 \\
\hline \multirow{4}{*}{ Daffodil } & ADY1 & $-23.3^{*}$ & -15.5 & $-44.9^{*}$ & $-57.7^{*}$ & $-30.5^{\star}$ & $-50.7^{*}$ \\
\hline & GAZ4 & $-30.2^{*}$ & -4.4 & $-31.2^{*}$ & $-57.1^{*}$ & $-40.6^{*}$ & -46.5 \\
\hline & $\mathrm{KAH} 2$ & -5.2 & -4.4 & $-25.7^{*}$ & $-43.3^{*}$ & -4.5 & -33.4 \\
\hline & KAS9 & $-22.9^{*}$ & -11.1 & $-34.8^{*}$ & $-57.4^{*}$ & -33.7 & $-50.7^{*}$ \\
\hline \multirow{4}{*}{ Garlic } & ADY1 & -19.6 & -11.4 & -30.8 & -25.0 & -37.2 & $-46.4^{*}$ \\
\hline & GAZ4 & -29.8 & -11.1 & $-30.8^{*}$ & -58.3 & 23.3 & -38.7 \\
\hline & $\mathrm{KAH} 2$ & $-23.5^{\star}$ & -15.5 & -38.5 & -50.0 & $-37.2^{*}$ & -40.5 \\
\hline & KAS9 & $-25.8^{*}$ & -22.2 & -30.8 & $-75.0^{*}$ & $-44.2^{*}$ & $-58.3^{*}$ \\
\hline \multirow{4}{*}{ Leek } & ADY1 & $-16.9^{*}$ & -22.4 & -36.6 & -50.0 & 13.3 & -39.8 \\
\hline & GAZ4 & -12.9 & -22.4 & -33.3 & $-54.2^{*}$ & -20.0 & -31.0 \\
\hline & $\mathrm{KAH} 2$ & -11.9 & -22.4 & -23.3 & -41.6 & -20.0 & -31.0 \\
\hline & KAS9 & 3.3 & -8.6 & -20.0 & -16.6 & 13.3 & -8.8 \\
\hline \multirow{4}{*}{ Lettuce } & ADY1 & 11.7 & -3.9 & -18.8 & -35.3 & -4.2 & 40.0 \\
\hline & GAZ4 & -16.9 & -5.8 & -8.3 & -29.8 & 9.9 & 58.4 \\
\hline & $\mathrm{KAH} 2$ & -14.8 & -12.5 & -10.4 & -45.3 & 2.8 & -9.6 \\
\hline & KAS9 & -1.64 & -7.8 & 10.4 & -5.8 & 2.8 & 46.4 \\
\hline \multirow{4}{*}{ Lucerne } & ADY1 & $-25.7^{*}$ & -10.7 & -40.0 & -40.6 & -25.4 & -28.0 \\
\hline & GAZ4 & $-11.9^{*}$ & -18.5 & 10.0 & -21.8 & -25.4 & $-37.6^{\star}$ \\
\hline & $\mathrm{KAH} 2$ & -19.2 & -41.5 & -20.0 & -43.7 & -2.9 & -20.0 \\
\hline & KAS9 & -7.7 & -41.5 & -10.0 & -12.5 & -12.3 & -36.0 \\
\hline \multirow{4}{*}{ Onion } & ADY1 & -5.0 & -3.3 & -14.9 & -37.4 & -27.0 & -15.7 \\
\hline & GAZ4 & -8.3 & -20.0 & 8.5 & $-23.1^{*}$ & 9.0 & 6.1 \\
\hline & $\mathrm{KAH} 2$ & 13.1 & 0.0 & -10.6 & $-35.2^{*}$ & -5.8 & -25.2 \\
\hline & KAS9 & -8.9 & 8.3 & 12.7 & -19.2 & 3.7 & -5.7 \\
\hline \multirow{4}{*}{ Wheat } & ADY1 & 8.5 & 23.6 & -20.0 & -29.3 & -12.3 & -33.5 \\
\hline & GAZ4 & 16.1 & 36.4 & 33.3 & -21.9 & -33.8 & -41.6 \\
\hline & $\mathrm{KAH} 2$ & 21.4 & 0.0 & -20.0 & -17.0 & -4.6 & 2.7 \\
\hline & KAS9 & 8.1 & 5.5 & -13.3 & $-34.1^{*}$ & 7.7 & -28.1 \\
\hline
\end{tabular}

* Differences between inoculated and uninoculated plants are significantly different according to the t-tests $(P<0.05)$.

With all nematode populations, stem diameter and plant fresh weight was reduced in inoculated daffodil. Mean stem diameter and shoot fresh weight reduced statistically significantly in all populations $(P<0.05)$ (Table 4). Other significant lower plant growth parameters in inoculated daffodil plants were the number of roots with ADY1 and KAS9 populations (Table 4). 


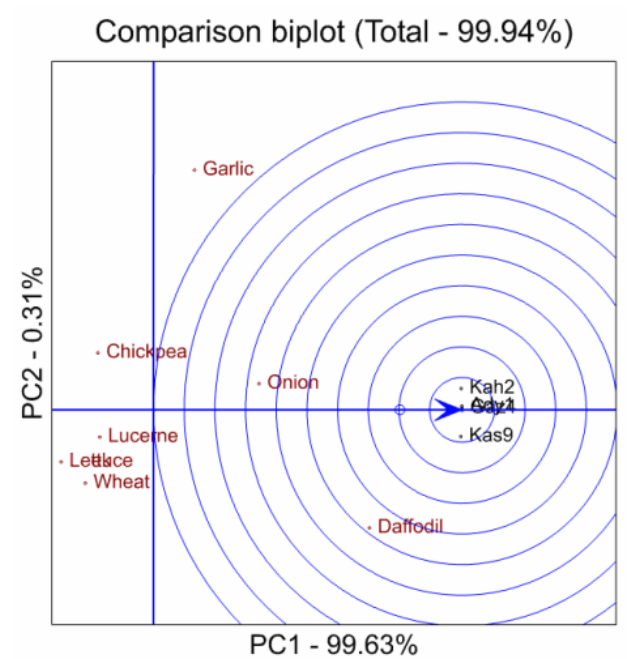

Figure 1. Biplot of reproduction factor of Ditylenchus dipsaci ADY1, GAZ4, KAH2 and KAS9 populations in chickpea, daffodil, garlic, leek, lettuce, lucerne, onion and wheat.

Garlic plant species had significantly lower plant growth parameters with nematode treatment. Mean shoot and root length decreased with KAH2 and KAS9 populations $(P<0.05)$ (Table 4). Number of roots in nematode inoculated plants with ADY1 and KAS9 populations was significantly lower (Table 4). Garlic shoot fresh weight was significantly lower in plants inoculated with KAS9 population $(P<0.05)$ (Table 4). Fresh weight of onion was significantly lower in plants inoculated with GAZ4 and KAH2 populations $(\mathrm{P}<$ 0.05) (Table 4).

Other significant changes in plant growth parameters with inoculation were lower stem diameter and number of leaves in chickpea with inoculation of KAH2 and KAS9 population, respectively. Although no nematode reproduction occurred in leek, shoot length (ADY1 population) and plant fresh weight (GAZ4 population) was found lower in inoculated plants (Table 4).

Mean shoot length of lucerne was significantly lower with inoculation with ADY1 and GAZ4 populations. Also, number of roots was significantly lower in nematode inoculated (GAZ4 population) lucerne plants $(\mathrm{P}<0.05)$ (Tables 4$)$.

\section{Discussion}

In this study, the host status of eight plant species of potential use in crop rotations for managing $D$. dipsaci in garlic was determined. Daffodil was found to be an excellent host, onion and garlic good hosts for D. dipsaci populations from garlic in South East Anatolia and Black Sea Regions in Turkey. In previous studies (Mennan, 2001; Yavuzaslanoglu \& Aksay, 2021) similar results for D. dipsaci populations from other geographic regions of Turkey were obtained. However, Yavuzaslanoglu \& Aksay (2021) did not obtain $D$. dipsaci reproduction daffodil, but it was found to be an excellent host in the current study. The reason for this could be the response of a different daffodil cultivar or difference in virulence of nematode populations applied. Whether this difference was due to the plant cultivar or nematode populations should be determined by investigating the host status of a range of daffodil cultivars to $D$. dipsaci populations. Also, in the current study, lower $R_{f}$ values were determined for onion and garlic plants than by Yavuzaslanoglu \& Aksay (2021) and were classified as good hosts rather than excellent hosts.

In a recent study (Poirier et al., 2019) in Canada, lucerne and lettuce were found to be non-hosts of a garlic population of $D$. dipsaci, similar to our study. Also, consistent with the findings of the present study, Hajihassani et al. (2016) reported that wheat was a non-host, chickpea cultivars were poor hosts and garlic a good host. 
Ditylenchus dipsaci populations have been shown to decrease significantly with 3-4 years of rotation with non-host plants (Hooper, 1984; Roberts \& Grathead, 1986). It is essential to know the host range of the population of $D$. dipsaci in an area in order to successfully design a crop rotation strategy to manage $D$. dipsaci. According to our results, lucerne, chickpea, wheat, lettuce and leek are non-hosts for $D$. dipsaci and this host status was not affected by the nematode population applied. Therefore, these plants can be recommended as rotational plants in garlic areas infested with $D$. dipsaci.

Shoot length, stem diameter, root length, number of roots and leaves, and whole plant fresh weight properties were used for evaluation of effect of $D$. dipsaci on the plants tested. Paralleling nematode reproduction, several plant growth parameters were identified to be affected by nematode inoculation. The non-host plant species in this study were unaffected.

To continue this work, it is necessary to test the non-host plant species identified in this study under natural infestation of $D$. dipsaci in the field and to consider their economic and agronomic value as rotational crops.

\section{References}

Abd-Elgawad, M. M. M. \& T. H. Askary, 2015. "Impact of Phytonematodes on Agriculture Ecology, 3-49". In: Biocontrol Agents of Phytonematodes (Eds. T. H. Askary \& P. R. P Martinelli). CAB International, 470 pp.

Ates Sonmezoglu, O., E. Yavuzaslanoglu, Z. Akar, A. Ocal, N. Genc, \& B. Terzi, 2020. Molecular characterization of Ditylenchus dipsaci on garlic in Turkey. Journal of Plant Disease and Protection, 127 (2): 165-171.

Chitambar, J., 2003. Preparing carrot discs for nematode culture. (Web page: http://nemaplex.ucdavis.edu/Methods/ CarrotDisc.htm) (Date accessed: 23.01.2021).

Duncan, L. W. \& M. Moens, 2006. "Migratory Endoparasitic Nematodes, 123-142". In: Plant Nematology (Eds. N. R. Perry \& M. Moens). CAB International, $568 \mathrm{pp}$.

Hajihassani, A., M. Tenuta \& R. H. Gulden, 2016. Host preference and seed-borne transmission of the stem nematodes, Ditylenchus weischeri and $D$. dipsaci on select pulse and non-pulse crops grown in the Canadian Prairies. Plant Disease, 100 (6): 1087-1092.

Hooper, D. J., 1984. Observations on stem nematode, Ditylenchus dipsaci, attacking field beans, Vicia faba. Rothamsted Experimental Station Report for 1983, Part 2: 239-260.

Hooper, D. J., J. Hallmann \& S. Subbotin, 2005. "Methods for Extraction, Processing and Detection of Plant and Soil Nematodes, 53-87". In: Plant Parasitic Nematodes in Subtropical and Tropical Agriculture (Eds. M. Luc, R. A. Sikora \& J. Bridge). CABI Publishing, 896 pp.

Janssen, G. J. W., 1994. The relevance of races in Ditylenchus dipsaci (Kühn) Filipjev, the stem nematode. Fundamentals of applied Nematology, 17 (5): 469-473.

Kühnhold, V., S. Kiewnick \& R. A. Sikora, 2006. Development of an in vivo Bioassay to Identify Sugar Beet Resistance to the Stem Nematode Ditylenchus dipsaci. Nematology, 8 (5): 641-645.

Mennan, S., 2001. Amasya Suluova İlçesi Soğan Ekim Alanlarında Soğan Sak Nematodu Ditylenchus dipsaci (Kühn, 1857) (Nematoda: Tylenchida: Anguinidae) Populasyonunun Bitki Koruma Yönünden Araştırılması. Ondokuz Mayıs University, (Unpublished) PhD Thesis, Samsun, Turkey, 137 pp (in Turkish with abstract in English).

Ocal, A., 2021. Determination of Plant Parasitic Nematodes in Major Garlic Production Areas of Turkey and Screening of Some Garlic Genotypes against Stem and Bulb Nematode Races [Ditylenchus dipsaci (Kühn, 1857) Filipjev, 1936]. Çukurova University, (Unpublished) PhD Thesis, Adana, Turkey, $121 \mathrm{pp}$ (in Turkish with abstract in English).

Poirier, S., N. Dauphinais, H. Van Der Heiden, P. Y. Veronneau, G. Belair, V. Gravel \& B. Mimee, 2019. Host range and genetic characterization of Ditylenchus dipsaci populations from Eastern Canada. Plant Disease, 103 (3): 456-460.

Roberts, P. A. \& S. A. Grathead, 1986. Control of Ditylenchus dipsaci in infected cloves by nonfumigant nematicides. Journal of Nematology, 18 (1): 66-73.

Seinhorst, J. W., 1957. Some aspects of the biology and ecology of stem eelworms. Nematologica, 2 (Suppl.): 353-361.

Shubina, L. V., 1992. Study of host range of the onion and garlic strains of stem nematodes, depending on soil and climatic. Trudy Gelminologicheskoi Laboratory, 39: 201-206. 
Sturhan, D. \& M. W. Brzeski, 1991. "Stem and Bulb Nematodes, Ditylenchus spp., 423-465". In: Manual of Agricultural Nematology (Eds. W. R. Nickle \& M. Dekker). Marcel Dekker Publications, 1035 pp.

Subbotin, S. A., M. Madani, E. Krall, D. Sturhan \& M. Moens, 2005. Molecular diagnostics, taxonomy and phylogeny of the stem nematode Ditylenchus dipsaci species complex based on the sequences of the inter transcribed spacer-rDNA. Phytopathology, 95 (11): 1308-1315.

Thorne, G., 1961. Principles of Nematology. McGraw Hill Publications, New York, 553 pp.

Viglierchio, D. R., 1971. Race genesis in Ditylenchus dipsaci. Nematologica, 17 (3): 386-392.

Yavuzaslanoglu, E. \& G. Aksay, 2021.Susceptibility of different plant species to two populations of Ditylenchus dipsaci Kühn, 1857 (Tylenchida: Anguinidae) from Turkey. Turkish Journal of Entomology, 45 (1): 77-86.

Yavuzaslanoglu, E., O. Ates Sonmezoglu, N. Genc, Z. M. Akar, A. Ocal, S. M. Karaca, I. H. Elekcioglu, V. S. Ozsoy \& M. Aydogdu, 2019. Occurrence and abundance of nematodes on onion in Turkey and their relationship with soil physicochemical properties. Nematology, 21 (10): 1063-1079. 